\author{
NBER WORKING PAPER SERIES \\ ON \\ HISTORICAL FACTORS IN LONG RUN GROWTH
}

\title{
"DEVELOPMENT, HEALTH, NUTRITION, AND MORTALITY: THE CASE OF THE ‘ANTEBELLUM PUZZLE' IN THE UNITED STATES”
}

\author{
Michael R. Haines \\ Lee A. Craig \\ Thomas Weiss
}

Historical Paper 130

\author{
NATIONAL BUREAU OF ECONOMIC RESEARCH \\ 1050 Massachusetts Avenue \\ Cambridge, MA 02138 \\ October 2000
}

This paper is based on two earlier papers presented at the conference "The Biological Standard of Living and Economic Development: Nutrition, Health, and Well-Being in Historical Perspective," held at the University of Munich, Munich, Germany, January 18-21, 1997. They have been published in John Komlos and Joerg Baten, eds., The Biological Standard of Living in Comparative Perspective (Stuttgart: Franz Steiner Verlag, 1998), pp. 155-180 and 190-207. This research was funded in part by the National Institute of Aging (AG 10120) and by the National Science Foundation (\#SBR-9408525). The authors wish to than Brian A'Hearn, Markus Heintel, and Robert Fogel for data and Joerg Baten, Timothy Cuff, Richard Easterlin, Stanley Engerman, Robert Gallman, John Komlos, John Murray, Richard Steckel, Robert Whaples, and participants at the Economic History Seminar at the University of California at Berkeley, the Economics Seminar at the College of William and Mary, and the Social Science Colloquium at Colgate University for valuable comments and suggestions on earlier versions. Part of this research was conducted by Craig while he was a German Marshall Fund Fellow at the Seminar fuer Wirtschaftsgeschichte at the University of Munich. The views expressed herein are those of the authors and not necessarily those of the National Bureau of Economic Research.

(C) 2000 by Michael R. Haines, Lee A. Craig, and Thomas Weiss. All rights reserved. Short sections of text, not to exceed two paragraphs, may be quoted without explicit permission provided that full credit, including (C) notice, is given to the source. 
"Development, Health, Nutrition, and Mortality:

The Case of the 'Antebellum Puzzle' in the United States"

Michael R. Haines, Lee A. Craig, and Thomas Weiss

NBER Historical Paper No. 130

October 2000

Development of the American Economy

\section{ABSTRACT}

The "Antebellum Puzzle" describes the situation of declining stature and rising mortality in the three decades prior to the American Civil War (1861-65). It is labeled a puzzle, since this period was one of rapid economic growth and development in the United States. Much of the debate regarding this puzzle has centered on whether the American diet, both in terms of protein and caloric intake, deteriorated in the mid-nineteenth century. But the mortality environment also appears to have worsened (or at least failed to improve), a situation associated with rapid urbanization, commercialization, transport improvement, and increased geographic mobility. The disease environment was being nationalized and internationalized.

This paper analyzes the relationship between local agricultural surpluses, nutritional status, mortality conditions, and adult heights. Employing a sample of the muster records of Union Army recruits (1861-65) as well as data from the published population and agricultural censuses of 1840 and mortality data from the 1850 census of population, it tests the hypothesis that adult height is positively correlated with local production of nutrients in early childhood and negatively correlated with local mortality conditions, urbanization, proximity to transport, and population mobility.

Results indicate that, although the United States was experiencing robust "Smithian" economic growth induced by transport improvements and widening markets, the nation was also suffering from serious negative externalities which affected the health and longevity of the population.

Michael R. Haines

Department of Economics

Colgate University

13 Oak Drive

Hamilton, NY 13346

and NBER

mhaines@mail.colgate.edu

Thomas Weiss

Department of Economics

University of Kansas

Summerfield Hall

Lawrence, KS 66045

and NBER

t-weiss@ukans.edu
Lee A. Craig

Department of Economics

North Carolina State University

Raleigh, NC 27695-7506

and NBER

lee_craig@ncsu.edu 
INTRODUCTION

The phenomenon of the "Antebellum Puzzle" of declining human stature in the three decades before the American Civil War (1861-1865) has presented serious issues in interpreting both the economic development and the demographic transition in the antebellum United States. It is a puzzle because the period 1800 to 1860 was one of rapid economic growth and structural change. For example, over these six decades the share of the population residing in urban areas (of 2,500 population and over) rose from $6.1 \%$ to $19.8 \%$. For the same period, agriculture's share in the labor force declined from 74.4\% to 55.8\%. Real GDP per capita grew at an average annual rate of almost one percent (.92\% per annum), which was at least $50 \%$ greater than the rate of growth in the preceding century. ${ }^{1}$ [See Table 1 and Weiss, 1992, pp. 22, 27.]

Similarly, real wages showed a strong upward trend during the era, rising by $1.14 \%$ per year from $1821 / 25$ to $1851 / 56 .^{2}$ In addition to these specific indicators, other measures, such as the commercialization of agriculture [Craig and Weiss, 1997], suggest a robust pace of modernization and economic growth.

In contrast to the picture painted by these economic data, other social indicators suggest deteriorating conditions during the several decades preceding the Civil War. For example, between 1800/04 and 1850/54, the expectation of life at age 10 (e(10)) fell from 55.2 years to 47.8 years [Fogel, 1986, Table 9.A.1]. During the same time period, there was a decline in the stature of adult males, representing a broad crosssection of antebellum society [Steckel, 1995; Komlos, 1987, 1996]. Figure 1 depicts these changes for the period 1780 to 1930. It shows series for e(10) and the heights of adult native white males (by birth cohort) [Fogel, 1986, Table 9.A.1; Haines, forthcoming (a), Table 3; Steckel, 1992, Table 6.8]. Expectation of life at age ten was falling from the early $19^{\text {th }}$ century and did not begin its sustained modern improvement until about 1880 [Haines, forthcoming]. Trends in adult male stature (by birth cohort) followed with a lag of about 10 to 30 years.

In addition to this, Komlos [1987, 1996] and Cuff [1992] contend that both the quality and quantity of protein and calories in the average American diet deteriorated from the $1830 \mathrm{s.}^{3}$ Standard measures of the distribution of wealth also show an increase in inequality between the late $18^{\text {th }}$ century and 1860 [Lindert, 1997, Table 3]. This failure to move toward economic equality had been noted by several social historians of the period [see, for example, Pessen, 1971; Wilentz, 1984].

Taken together, these two sets of information - the former offering an "optimistic" view and the latter a "pessimistic" view of the economic development of antebellum America - form the "Antebellum Puzzle" [Komlos, 1996]. Added to this 
puzzle is another demographic dimension - birth rates were falling and female marriage age was rising. Haines [2000a] believes that they are related and has put forth a Malthusian explanation of the antebellum puzzle and the demographic transition. Although the American economy in this era did not experience any dramatic, classic Malthusian crises, it was subject to significant preventive Malthusian checks, expressed as declining fertility within marriage and likely rising age at marriage.

This was not an isolated phenomenon. Recent new evidence has shown deteriorating mortality conditions in the large cities of England up to the middle of the $19^{\text {th }}$ century [Szreter and Mooney, 1998]. This accompanied the rapid industrialization, urbanization, and economic growth of Britain in this period and was paralleled by a decline in children's growth profiles [Floud, Wachter, and Gregory, 1990, pp. 205-207, 288-295]. Szreter [1997], based on this British evidence, notes that rapid economic growth can engender environmental, social, administrative, and political disruption, and argues that without effective political and administrative responses, societies will suffer increased deprivation, disease, and mortality. The same was true for large cities in the United States in the antebellum period [Haines, 1999].

In this paper, we employ both aggregated and micro-level data for the United States to examine two aspects of the antebellum situation. First, evidence of a type of "positive" Malthusian check would be a negative relationship between nutritional availabilities and mortality. The test here is the covariation between local nutritional surpluses (for both proteins and total calories) and the crude death rate for counties. Second would be a negative relationship between mortality and adult stature. This latter issue is investigated jointly with the effect of nutritional surpluses on heights. These are not tests of a classic Malthusian crisis, but rather the presence of an antebellum "Malthusian squeeze" [Haines, 2000]. In effect, we investigate whether economic development itself might have had unintended negative effects on health and longevity.

THE ANTEBELLUM ECONOMY AND SOCIETY IN THE UNITED STATES

As mentioned above, the period 1790 to 1860 , the antebellum or early national period of American history, has been seen as one of rapid growth and development. A series of social and economic indicators for the period are presented in Table 1. Despite the fact that population was growing at historically quite extraordinary rates (nearly 3\% per year for the six decades 1800-1860), real GDP per capita still managed to grow at $0.9 \%$ per annum for the same period. For the last three decades (1830-60) 
the average annual growth rate of real GDP per capita was $1.33 \%$

This was also a period marked by significant immigration and increased commercialization. Over 5.7 million immigrants entered the nation between 1800 and 1860, such that by 1860 the population was 13\% foreign born. Of the free native-born population in 1860 whose birthplace was known, 24.8\% had been born in a state different from that of current residence [calculated from U.S. Bureau of the Census, 1864, p. xxxiil]. By 1860, almost 20\% of America's population was living in urban places, in contrast to about $6 \%$ at the beginning of the century. On the eve of the Civil War the United States could boast about 3,700 miles of canals and almost 31,000 miles of railroads, not to mention an immense natural endowment of navigable waterways. Despite the huge immigration over the last two decades of the antebellum period (about 28\% of total population growth) [calculated from Haines, 2000b, Table 1], real agricultural output per capita was growing (see Table 1). Despite this growth in real agricultural output per capita, however, nutrition may not have been improving, since estimated available protein and calories per capita per day were falling in the 1840s (not taking into account waste, seed, and animal feed). Also, non-food cash crops, notably cotton, were increasing in importance.

Paradoxically, however, two social indicators, stature and mortality, pointed to deteriorating conditions towards the end of the antebellum era. Table 1 and Figure 1 show that mean adult male heights declined from $173.5 \mathrm{~cm}$ for the birth cohort of 1830 to $170.6 \mathrm{~cm}$ for the cohort of 1860 - a loss of nearly an inch in height. Similarly, mortality likely increased over the first half of the $19^{\text {th }}$ century, preceding the decline in heights.

Unfortunately we know less about mortality in the United states in the period 1800 to 1860 than we do for any other era [see Haines, 1998, 2000b]. The figures on e(10) in Table 1 and Figure 1 are derived from genealogical data [Fogel, 1986; Pope, 1992]. They are not extended back to ages below ten and have issues of representativeness. Although the United States was the first nation to mandate regular census enumerations (from 1790), vital statistics collection was left to state and local governments. Consequently, progress in this area was uneven and tardy. Massachusetts was the first state to institute regular vital registration (in 1842), but it was not deemed complete until the mid-1850s [Gutman, 1956]. It was only in 1900 that the official Death Registration Area was formed (consisting of ten states and the District of Columbia)." The Birth Registration Area came even later (in 1915).

The census was used as early as 1850 to try to remedy the situation. The 
mortality data collected from the census must, however, be used with caution. The data were collected using a question on whether there was one or more deaths in the family or household in the year prior to the census (in this case June 1, 1849 to May 30, 1850). There was substantial underreporting of deaths, particularly at the youngest and oldest ages [Haines, 1979; Condran and Crimmins, 1979]. The Census Bureau was aware of the problem, stating in connection with the mortality report of the 1860 census "It is very apparent that the whole number of deaths which occurred in the year was not furnished." The report goes on to note likely causes: death of a family or household head, resulting in the breakup of the family or household and not reported; lack of information by the respondent; deaths not in families or households (e.g., institutions, boarding houses, ships); reference period error (i.e., not remembering whether the death occurred within the time period asked); deaths of non-relatives [U.S. Bureau of the Census, 1866, pp. xxiii-xxiv]. Some comparisons of census mortality data to registration data for Massachusetts and New Jersey in $1879 / 80$ indicate overall underreporting in the census of about 35-45\% [Condran and Crimmins, 1979, Table 6]. There is, however, no strong reason to believe that underreporting varied greatly by location or region in 1850. Differences in age/sex composition likely had no great impact on differential undercount of total deaths. Finally, a significant cholera epidemic took place during the early part of the census year (in 1849), and, ironically, helped bring mortality levels closer to those of "normal" years [Vinovskis, 1978; Rosenberg, 1962]. Consequently, the crude death rates estimated from these data are inflated by $40 \%$

The last column of Table 1 presents some mortality estimates made using genealogical data [Fogel, 1986; Pope, 1992]. These too must be used with care. The estimates do not cover infant and childhood mortality, and there are issues of representativeness. Nonetheless, they do indicate that mortality was rising over the first half of the $19^{\text {th }}$ century. Some additional suggestive evidence is seen in Figure 2, the crude death rate for New York City over the period 1804 to 1920. This shows rising mortality over the first half of the $19^{\text {th }}$ century and also rather dramatic mortality fluctuations, particularly before mid-century.

\section{MORTALITY IN ANTEBELLUM AMERICA}

The first test of an antebellum Malthusian squeeze involves the relationship between nutritional access and mortality. The standard Malthusian model predicts that populations experiencing nutritional shortfalls would experience higher death rates 
than other populations. In addition to nutritional shortfalls, exposure to disease was an important component of Malthus's positive checks. Of course nutrients could be purchased from other regions if they were not produced locally, and the wealthy could afford to escape to healthier environs upon realizing the probability of exposure to disease had increased; so wealth might have played a role in ameliorating the effects of nutritional deficits and disease on mortality.

One can estimate the potential effects of these and other factors on mortality from the following equation:

\section{(1) $\mathrm{CDR}_{J}=\alpha+\mathrm{B}_{1}$ NUTRITION $_{j}+\mathrm{B}_{2}$ HINDEX $_{j}+\mathrm{B}_{3}$ WEALTH $_{j}+\mathrm{B}_{4}$ TRANSPORT $_{j}+\mathrm{B}_{5}$ URBAN $_{j}+\boldsymbol{\epsilon}_{\mathrm{J}}$}

where $\mathrm{CDR}_{j}$ is the crude death rate in the $j$ th county in $1850 .{ }^{5}$ NUTRITION $_{j}$ is the marketable surplus of protein (PROTEIN) or calories (CALORIES) in the county in 1840. HINDEX $_{j}$ is the Herfindahl index of concentration of the source of the nutrients (i.e. meat, grain, etc.) in the county. ${ }^{6}$ WEALTH$_{j}$ is the sum of agricultural and industrial wealth (per capita) in the county in 1850. TRANSPORT is 1 if the county was on a navigable waterway in 1840, 0 otherwise. Finally, URBAN is the proportion of the county's population living in an urban area in 1840. 7 For quick reference, Table 2 contains a brief description of each of these variables in addition to the means and standard deviations.

Among effects on mortality that interest us are those that result from measures of net protein production - that is, PROTEIN and CALORIES. The data for the calculation of these variables were collected from the published volumes of the Sixth Census of the United States. ${ }^{8}$ After we obtained the matrix of farm output for each county in the United states in 1840, we converted that matrix into two vectors of nutrition - one containing kilograms of protein and the other kilocalories. ${ }^{9}$ We then subtracted mean human, livestock, and seed requirements from those figures. ${ }^{10}$ The resulting vectors represent the marketable surpluses of protein and calories for every county in the United states in 1840. In equation (1) $\beta_{1}$ captures the effect of nutritional access on mortality, and the Malthusian model would predict that it should be negative. This is supported by the evidence shown in Table 3 that the mean death rates in counties with nutritional deficits was more than four deaths per thousand greater than those with surpluses, a difference that was statistically significant.

Recent work by Baten [1996a, 1996b] suggests that it was not only the quantity of net nutrition that determined the biological standard of living; the source or type of 
the nutrients played an important role as well, especially protein coming from dairy products. In an earlier work, Craig and Weiss [1998] found no such relationship. Whether tested, separately or in various linear combinations, the share of nutrients coming from, say, meat, dairy products, grains, or other foodstuffs does not appear to have influenced individual stature. Some other recent research relates to this issue. For example, work by Coclanis et al. [1995] suggests that commercialization contributed to a worsening of the local nutritional environment. This effect would have been manifested when increases in commercialization that were correlated with increased specialization led farmers to ship nutrients out rather than consume them locally.

In order to try to capture this effect, we calculated Herfindahl indices of concentration, HINDEX, of the source of the nutrients produced in each county and tested for their role in the Malthusian squeeze. In this case, a more highly concentrated combination of outputs, that is higher values of HINDEX, would be associated with higher local death rates $-\beta_{2}>0$. On the other hand, Gregson [1993, 1994] and Bogue [1993] suggest that the sign could go the other way. In their view, commercialization and specialization did not necessarily move in the same direction, and indeed likely moved in opposite directions. Thus one interpretation of this issue is that if there were a higher degree of commercialization, then a lower value of HINDEX capturing the Gregson effect should be associated with higher death rates $\beta_{2}<0$. Table 3 indicates that higher values of the Herfindahl index for protein availability was associated with higher death rates, supporting the first view; that is, to the extent that commercilization is reflected in the Herfindahl index, it appears to have a negative impact on mortality, as Coclanis et al. [1995] suggest.

For wealth by county, we had to use a proxy measure. The Sixth U.S. Census (1840) does not contain information on household wealth, so we have used the sum of the value of agricultural (value of farm, implements, and livestock) wealth and manufacturing assets per capita that were reported in the Census for 1850 as our measure of local wealth. Based on the observation that wealth tends to be an autoregressive process, we are assuming that a county that was relatively wealthy in 1850 was also relatively wealthy in $1840 .{ }^{11}$ As we argued above, access to nutrition and the avoidance of disease-ridden environs might logically be related to measures of income and wealth, thus we expect the coefficient on WEALTH, $\beta_{3}$, to be negative. The figures reported in Table 3, however, show that there was a positive association of death rates across counties with various amounts of per capita wealth. This is consistent with the view 
that wealthier areas were those with more urbanization and greater levels of commercialization and better transport connections. In short, wealthier areas were those developing more rapidly.

The dummy variable for transportation, TRANSPORT, is included to capture the possible effects from access to the regional transportation network. ${ }^{12}$ In 1840 , this network was primarily water transportation; rivers, canals, lakes, and the Atlantic Ocean. This regional and international transportation network had potentially conflicting effects on the economic conditions and mortality of those living in counties with access to it. On the one hand access to transportation would have lowered the cost of obtaining nutrition, suggesting the coefficient on TRANSPORT, $\beta_{4}$, would be negative. On the other hand, transportation also facilitated the movement of nutrients out of a surplus region and facilitated the inward movement of people and hence disease. Both the increased export of the surpluses and the import of diseases would have reduced net nutrition. In an earlier paper, Craig and Weiss [1997] found that the deleterious effects from disease and sale of surpluses outweighed the positive benefits of lower-cost access to nutrition, and so we expect in the current estimation that the sign of $\beta_{4}$ will be positive; access to transportation led to less nutrition and thus a higher mortality rate. As shown in Table 3, counties with transportation access had on average significantly higher death rates (almost five per thousand) than those without such access.

Finally, we have included the share of the population residing in an urban area in the county to capture the disamenities of urban life, particularly exposure to disease because of crowding, high turnover of population, polluted water supplies, and inadequate disposal of sewage and rufuse, which would have led directly to greater death rates, and indirectly as well because disease places biological demands on nutrition which would have further contributed to higher mortality rates. In short, a larger urban population would have been positively correlated with death rates. ${ }^{13}$ Therefore, after controlling for nutrition, wealth, and access to transportation, we expect $\beta_{5}$, the coefficient on URBAN, to be positive. The figures in Table 3 support this idea, as mean death rates were significantly higher in counties with larger urban shares of the population. Those counties with more than 25\% urban population in 1840 had almost eight deaths more per thousand population relative to those counties with less than $1 \%$ urban population.

Table 4 contains the results from estimating four variations of equation (1) for the counties of the United States in 1840. The results show that in no specification 
were the effects from our two measures of nutritional surpluses, PROTEIN or CALORIES, statistically significant. This is a decidedly non-Malthusian result. On the other hand, both transportation access and urbanization directly and significantly affected death rates. Access to regional transportation networks via a water route increased the death rate by about four per thousand. And a ten percentage point increase in the share of a county's population living in an urban area resulted in an increase of 1.3 to 1.4 deaths per thousand.

The Herfindahl indices, measuring the concentration of protein and calorie production in a county, did have positive effects on the county's death rate, and the coefficients were statistically significant at the five and one percent levels for protein and Kcalories respectively. It appears that the source or type of nutrition did matter, although it seems to have done so in a harmful way; greater specialization was in some way, perhaps through commercialization, associated with higher death rates. To put the impact in perspective, consider that an increase in specialization of one standard deviation from the mean (about .09 points on the Herfindahl index for protein) would have led to an increase on average of 0.6 deaths per thousand. This result appears to be consistent with the effects of the expansion of agricultural markets in general suggested in Coclanis et al. [1995].

Overall, we would conclude that the results in Table 4 show negative feedbacks between economic and social change and the mortality environment, but are only partly supportive of a traditional Malthusian scenario via nutrition and the food supply.

STATURE AND THE ANTEBELLUM PUZZLE ${ }^{14}$

Another way in which an antebellum Malthusian squeeze might have been manifest was through the effects of nutritional deficits and disease on adult height. Craig and Weiss [1997] offer a model of the relationship between adult height of the ith individual, $\mathrm{HEIGHT}_{i}$, and the supply of nutrients in the locale in which the individual spent infancy, NUTRITION ${ }_{i}$. Their empirical estimates suggest a statistically strong, though arguably economically small, effect of access to nutrition in infancy on adult height. This view is supported by studies in contemporary developing nations which show that terminal adult heights are largely influenced by disease and nutritional conditions early in life (i.e. the first two years) [Martorell and Habicht, 1986]. This relationship holds ceteris paribus of course, and other economic variables would have played some part. In particular, the mortality environment in which an individual was raised was related to other factors, such as exposure to disease, and 
therefore would have probably been indicative of any Malthusian squeeze that affected human stature.

Thus the biological relationship between the net consumption of nutrients in infancy and exposure to disease on the one hand and adult height on the other, and the economic relationship between the local production of nutrients and economic well being represented by adult height, can both be tested by matching adult height with economic and mortality conditions in the location in which an individual was born. In order to conduct this test, we have matched the adult height of a sample of Union Army recruits with a combination of personal variables and variables that reflect the economic environment of the locale in which the individual spent infancy. Just as our discussion above concerning death rates indicates, other economic variables might have affected stature, and these would include the concentration of the source of nutrients, wealth, access to transportation, and the extent of urbanization.

To test for these relationships we estimated the following equation:

$$
\begin{aligned}
\text { HEIGHT }_{i}= & \boldsymbol{\alpha}+\mathrm{B}_{1} \text { MOVER }_{i}+\sum_{\mathrm{t}=1862}^{1865} \mathrm{~B}_{2 \mathrm{tt}} \text { YEAR }_{i}+\mathrm{B}_{3} \text { FARMER }_{i}+\mathrm{B}_{4} \text { LABORER }_{i}+\mathrm{B}_{5} \text { NUTRITION }_{i}+ \\
& \text { B }_{6} \text { HINDEX }_{i}+\mathrm{B}_{7} \text { WEALTH }_{i}+\mathrm{B}_{8} \text { TRANSPORT }_{i}+\mathrm{B}_{9} \text { URBAN }_{i} \text { or } \text { B }_{10} \text { CDR }_{i}+\boldsymbol{\epsilon}_{i}
\end{aligned}
$$

where $\mathrm{HEIGHT}_{i}$ is the height in inches of the ith Union Army recruit. MOVER is a dummy variable, which takes the value 1 if the recruit enlisted in county other than the one in which he was born, 0 otherwise. $\mathrm{YEAR}_{\text {it }}$ is 1 if the ith recruit enlisted in the th year, 0 otherwise. The remaining variables are the same as those discussed in the previous section. Table 5 contains brief descriptions, means, and standard deviations of each of the variables in equation (2).

Our sample is from the data on 39,616 recruits in white regiments in the Union Army collected by Fogel, Engerman, et al. [n.d.] and includes all native-born recruits born between 1838 and 1842 for whom information was available on county of birth, county of enlistment, and adult height. The recruits who passed this test were matched with data reflecting economic conditions in 1840 in their county of birth; this process yielded 6,720 matches. Some of these matches, however, represented but a single recruit in a county, while in some other counties there were only a few recruits. Although genetic factors do not explain differences across populations, at the individual level they do matter. In these cases where there is only one or a few recruits, perhaps brothers, in a county, the genetic effect may have dominated all the other factors influencing height. In order to abstract from this particular source of bias we dropped all observations from counties for which there were fewer than five 
recruits in the matched sample. As a result we reduced our sample to 6,540 matches. We would have liked to have had annual economic data for each county to match with the infancy and early childhood of each recruit, but in the absence of such data we relied on those collected by the U.S. census of $1840 .^{15}$

As discussed in the previous section, we also collected information on the county in which a recruit enlisted. Although we know the county in which the recruit was born, we could not be certain that he spent his childhood in the same county. It would seem, however, that recruits whose county of birth was the same as county of enlistment had a substantially higher probability of having spent infancy in their county of birth. The coefficient corresponding to the dummy variable Mover reflects the difference between "movers" and "stayers" - that is, between those who probably spent their entire formative years in one location and those who did not. It is not immediately obvious to us what the sign of this effect should be. On the one hand, stayers usually stay because they are successful relative to movers or they might stay in relatively bountiful areas; on the other hand, moving may be a self-selecting activity for more ambitious individuals and families. ${ }^{16}$ Table 6 contains a comparison of the mean heights of recruits in various groups. It shows that movers were on average slightly taller than stayers, suggesting that the economic advantages of moving might have yielded nutritional advantages for the children of movers.

We also included a set of dummy variables for enlistment $\mathrm{YEAR}_{t}$. With respect to the heights of recruits, the policies of the Union Army administration, which are discussed in detail in Shannon [1928, vol. 2, passim] and reviewed in Craig and Weiss [1998], became, shall we say less selective over time. So we would expect that the year dummies would have negative signs and possibly get larger in absolute value over time. Table 6 compares the mean height of recruits inducted in each year with the mean from the previous year. There was an uneven decline in average heights from the recruits of 1862. In two of the four years following the onset of the war, the recruits were on average significantly shorter than those from the previous year.

Variables were also included for the occupation of the recruits, notably whether the recruit listed an occupation as either a farmer or a laborer. of the restricted sample of recruits considered here, about 97\% listed some occupation. Almost 59\% listed occupation as farmer and another 7\% as laborer (essentially non-specific unskilled work). It is expected that farmers would be taller, having better access to foodstuffs and also the protection against disease, such as it was, of living in rural areas. Laborers, being at the bottom of the socioeconomic occupational hierarchy, 
should be less advantaged in terms of upbringing, nutrition, and urban residence. As Table 6 shows, farmers were 0.7 inches taller than non-farmers, and laborers were slightly (0.2 inch) shorter than other recruits. Both differences were statistically significant.

Concerning the county-level variables in equation (2), we would in general expect them to have the opposite sign from our expectations with respect to death rates. Greater wealth would tend to be associated with greater human stature; whereas, the concentration of agricultural production, transportation access, urbanization, and higher mortality would have tended to reduce height. With the exception of the Herfindahl index of protein production, the tests of the differences in the means, which are reported in Table 6, support each of these conjectures. The results on wealth are ambiguous, with the poorest counties having the shortest recruits while the richest counties (having per capita wealth greater than $\$ 250$ ) had recruits shorter than counties in the intermediate range.

The results from estimating various versions of equation (2) for the sample of Union Army recruits are reported in Table 7. Models (1) to (4) use URBAN, while models (5) to (8) include the county crude death rate as measures of the urbanization/mortality effect. ${ }^{17}$ In general, the nutrition variables are positive and statistically significant. Our protein variable is measured in hundreds of grams per adult equivalent per day; so, the coefficients in models (1), (2), (5), and (6) indicate that an individual who spent infancy in a county that produced a net protein surplus one standard deviation (138 grams) above the mean would have been about one to two tenths of one inch taller as an adult, ceteris paribus, than someone from the average county. ${ }^{18}$ Similarly, a surplus of one standard deviation (2950 calories) above the mean in calorie production would have yielded an additional 0.06 to 0.16 inches in adult height (depending on the model).

Likewise, the mortality environment in the county in which a recruit spent his infancy seems to have played an important role in determining his adult stature. Living in a county with a crude death rate one standard deviation above the mean that is, an additional 8 deaths per thousand - led to a reduction of 0.11 to 0.13 of an inch in adult stature on average.

The coefficients on the Herfindahl variables indicate that the extent to which the sources of protein and calories were concentrated was important. The coefficients for HP and HC were significant and positive. It appears that both the quantity and concentration of the source of nutrition were relevant. 
A comparison of the results from Craig and Weiss's earlier study of the effect of nutrition on height with the present one is illuminating because the former did not take into account the impact of the disease environment as captured by the mortality variable. The effect of the nutritional surpluses is very nearly the same in both cases. The coefficients are similar in both studies. In the previous one that for the protein surplus was 0.141, and here it is 0.143 (for Model (5)); for calories the coefficients are 0.047 versus 0.055 (for Model (7)). The impact on heights is also similar, but the calculations of calorie and protein surplus differ a bit between the two studies. ${ }^{19}$ In the previous study, having spent infancy in a county with surplus protein production one standard deviation (about 70 grams) above the mean would have meant an extra one-tenth of an inch; in the present study the impact is about one to two tenths of one inch. For calories the previous study showed an effect of one-fifth of an inch, the current study .06 to 0.16 inches.

Although the concentration, wealth, and transportation variables show no statistically significant effect on adult stature, the other variables seem to be generally consistent with the expectations generated from the literature. For example, for every 10 percentage point increase in the urban share of the population, adult height would have been reduced by slightly more than one-tenth of an inch. With respect to the variables corresponding to the individual rather than the county in which he was born, moving from the county in which you were born had a positive, and statistically significant, effect on adult height; those who enlisted in a county different from that in which they were born were on average 0.12 to 0.15 inches taller than "stayers". As we noted above, this result could not have been unambiguously predicted, and it would seem to indicate that movers were relatively more successful than stayers, at least in providing their children with nutrients. Finally, the dummy variables denoting year of enlistment were negative after 1862, as expected, and by the last year of the war, the effect was quite large, with the 1865 recruits being on average nearly a half an inch shorter than those who enlisted before 1862.

CONCLUSIONS

Was the antebellum economy subject to a Malthusian squeeze? Probably not, at least not unambiguously. County-level crude death rates tended to rise with urbanization and access to the growing national transportation network, but these effects were at least partially caused by the increasing productivity of the agricultural sector. After all, cities can only prosper if their inhabitants are 
being fed by the countryside, and antebellum canals and rivers were largely used to transport agricultural surpluses. Furthermore, we uncovered some, albeit modest, evidence that death rates varied positively with the specialization of local agricultural production. If specialization was correlated with marketable surpluses, then that too would suggest a non-Malthusian explanation of cross-county mortality.

On the other hand, it seems clear from our results that the mortality environment in the area in which an individual spent infancy played an important role in the in the determination of adult stature as did nutritional access, and urbanization, the expansion of the transportation network. In addition the commercialization of agriculture probably played some role in mortality and nutritional access. While this was not a Malthusian crisis in the conventional sense, which is typically associated with some deficiency in the production of food, it did reflect a negative feedback from the economy to the demographic environment. Although the United States experienced robust economic growth in the decades immediately preceding the Civil War, there also were negative consequences for mortality and health, and it took a number of subsequent decades of economic growth (and the mortality transition itself) before the squeeze was alleviated.

These results confirm that the "Antebellum Puzzle" of declining heights in the face of robust economic growth was a real phenomenon. The results in Tables 4 and 7 also suggest some of the causes. Rapid economic development in the United States in the three decades prior to the Civil War were characterized by fast urban growth, significant migration from abroad, considerable internal mobility, great changes in the transportation infrastructure, and increased commercialization, including in agriculture. These all contributed to a worsening mortality environment which had adverse consequences for human growth. This may be characterized as "Smithian" growth via extension of markets with negative externalities. Elsewhere it has been shown that the shortest recruits were born in New England and the Middle Atlantic region and from more urban counties with higher proportions of foreign born [Haines, 1998b]. All this suggests that mortality was not unimportant to the "Antebellum Puzzle". Being born in a county with water connections in 1840 also is consistent with both a contagion and a commercialization view. The result that farmers were taller and that laborers were shorter is also supportive of these rural-urban effects. The latter is, however, also indicative of the possibility of rising inequality. Laborers were more likely to be urban dwellers and to be low on the socioeconomic status scale. Farmers were more likely to have had more wealth and an independent source of food, in 
addition to having been rural folk.

The issue of deteriorating nutrition also receives support here. Other inquiries [Komlos, 1987, 1996; Craig and Weiss, 1998] do point to that. If so, it could well have been a consequence of increased commercialization and the loss of a varied subsistence diet, as well as rising inequality. A more direct test of commercialization using the Herfindahl indices of sources of protein and calorie surpluses did not support this, however. The effects of the sizes of the surpluses, and not their composition, is more consistent with a positive role for local nutritional availability than of the negative impact of commercialization.

Overall, then, the "Antebellum Puzzle" seems to have resulted from a complex set of factors, including urbanization, increased population mobility, worsening mortality conditions, greater contact via improved transport infrastructure, and deteriorating nutrition. It seems that the growing prosperity of the United states in the antebellum period was partly purchased at a price of some deterioration of the biological standard of living. This situation did not rectify itself until the end of the $19^{\text {th }}$ century, when heights began to rise and when mortality began to decline, especially in urban areas. 


\section{REFERENCES}

Atack, Jeremy and Peter Passell. 1994. A New Economic View of American History, 2nd edition. New York: W.W. Norton.

Baten, Jörg. 1996a. "Der Einfluß von regionalen Wirtschaftsstrukturen auf den biologischen Lebensstandard. Eine anthropometrische Studie zur bayerischen Wirtschaftsgeschichte im frühen 19. Jahrhundert", Vierteljahresschrift für Sozial- und Wirtschaftsgeschichte. Vol. 83, No. 2. pp. 180-213.

Baten, Jörg. 1996b. "Der Einfluß von Einkommensverteilung und Milchproduktion auf die regionalen Unterschiede des Ernährungsstandards in Preussen um die Mitte des 19. Jahrhunderts: Ein anthropometrischer Diskussionsbeitrag." Archiv für Sozialgeschichte. Vol. 36. pp. 69-83.

Bogue, Allan G. 1993. "Communication." Agricultural History. Vol. 67, No. 4 (Fall). pp. 105-107.

Coclanis, Peter, Paul Katzenberger, and John Komlos. 1995. "On the Puzzling Cycle in the Biological Standard of Living in the Antebellum United States." Paper presented the Triangle Universities' Economic History Workshop.

Condran, Gretchen, and Eileen Crimmins. "A Description and Evaluation of Mortality Data in the Federal Census: 1850-1900," Historical Methods. Winter 1979, 12(1), pp. $1-23$.

Craig, Lee A. 1993. To Sow One Acre More: Childbearing and Farm Productivity in the Antebellum North. Baltimore: The Johns Hopkins University Press.

Craig, Lee A. and Thomas Weiss. 1997. "Long Term Change in the Business of Farming: The Rise of the Marketable Surplus." Paper presented at the Business History Conference, Glasgow, Scotland.

Craig, Lee A. and Thomas Weiss. 1998. "Nutritional Status and Agricultural Surpluses in the Antebellum United States." In John Komlos and Joerg Baten, eds. The Biological Standard of Living in Comparative Perspective. (Stuttgart: Franz Steiner Verlag). pp. $190-207$.

Craig, Lee A., Raymond Palmquist, and Thomas Weiss. 1998. "Transportation Improvements and Land Values in the Antebellum United States: A Hedonic Approach." Journal of Real Estate Finance and Economics. Vol. 16, No. 2 (March). pp. 173-189.

Cuff, Timothy. 1992. "A Weighty Issue Revisited: New Evidence on Commercial Swine Weights and Pork Production in Mid-Nineteenth Century America." Agricultural History. Vol. 66, No. 4 (Fall). pp. 55-74.

Ensminger, Audry H., M.E. Ensminger, James E. Korlande, and John R. K. Robson. 1994. 
Foods and Nutrition Encyclopedia. 2 vols. 2nd Edition. Boca Raton, FL: CRC Press.

Floud, Roderick, Kenneth Wachter, and Annabel Gregory. 1990. Height, Health, and History: Nutritional Status in the United Kingdom, 1750-1980. NY: Cambridge University Press.

Fogel, Robert W. 1986. "Nutrition and the Decline in Mortality since 1700: Some Preliminary Findings," In Stanley L. Engerman and Robert E. Gallman, eds. Long-Term Factors in American Economic Growth. (Chicago: University of Chicago Press). pp. 439555.

Fogel, Robert W., Stanley L. Engerman, et al. (n.d.). "Union Army Recruits in White Regiments in the United States, 1861-1865." Inter-University Consortium for Political and Social Research. Study No. 9425.

Gallman, Robert E. 1995. "Pork Production and Nutrition During the Late Nineteenth Century: A Weighty Issue Revisited Yet Again." Agricultural History. Vol. 69, No. 4. (Fall). pp. 592-606.

Gallman, Robert E. 1996. "Dietary Change in Antebellum America." Journal of Economic History. Vol.56, No. 1 (March). pp. 193-201.

Gregson, Mary Eschelbach. 1993. "Specialization in Late Nineteenth-Century Midwestern Agriculture." Agricultural History. Vol. 67, No. 1 (Winter). pp. 16-35. Gregson, Mary Eschelbach. 1994. "Reply to Professor Bogue." Agricultural History. Vol. 68, No. 1 (Winter). pp. 127-128.

Gutman, Robert. 1956. "The Accuracy of Vital Statistics in Massachusetts, 1842-1901." Unpublished Ph.D. Dissertation. New York: Columbia University. Haines, Michael R. 1979. "The Use of Life Tables to Estimate Mortality for the United States in the Late Nineteenth Century." Demography. (May) Vol. 16, No. 2. pp. $289-312$.

Haines, Michael R. 1998a. "Estimated Life Tables for the United States, 1850-1900." Historical Methods. Vol. 32, No. 4 (Fall). pp. 149-169.

Haines, Michael R. 1998b.

Haines, Michael R. 1999. "The Urban Mortality Transition in the United States, $1800-$ 1940." Paper presented at the "The Demographic Forum 1999", Norwegian Academy of Sciences, Oslo, Norway, June 10-13.

Haines, Michael R. 2000a. "Malthus and North America: Was the United States Subject to Economic-Demographic Crises?" In Tommy Bengtsson and Osamu Saito, eds. Population and Economy: From Hunger to Modern Population Growth. NY: Oxford University Press.

Haines, Michael R. 2000b. "The American Population, 1790-1920." In Stanley Engerman and Robert Gallman, eds. The Cambridge Economic History of the United States. Vol. 2. 
"The Long Nineteenth Century." NY: Cambridge University Press.

Komlos, John. 1987. "The Height and Weight of West Point Cadets: Dietary Change in Antebellum America." Journal of Economic History. Vol.47, No. 4 (Dec.) . pp. 897-927.

Komlos, John, ed. 1994. Stature, Living Standards, and Economic Development: Essays

in Anthropometric History. Chicago: University of Chicago Press.

Komlos, John. 1995. The Biological Standard of Living in Europe and America, 1700-

1900. Aldershot, Eng.: Variorum.

Komlos, John. 1996. "Anomalies in Economic History: Toward a Resolution of the

'Antebellum Puzzle'." Journal of Economic History. Vol.56, No. 1 (March). pp. 202-214.

Lindert, Peter H. 1997. "Three Centuries of Inequality in Britain and America."

Department of Economics, University of California at Davis. Working Paper \#97-09.

Lipton, Kathryn L. 1995. Dictionary of Agriculture From Abaca to Zoonosis. London:

Lynne Rienner Publishers.

Mancall, Peter and Thomas Weiss. 1997. "Conjectural Estimates of Gross Domestic Product per Capita in Colonial Mainland British America." (Mimeo). University of Kansas, revised version of a paper prepared for the Conference on the Economy of Early British America.

Margo, Robert. 1992. "Wages and Prices during the Antebellum Period: A Survey and New Evidence." In Robert E. Gallman and John Joseph Wallis, eds. American Economic growth and Standards of Living Before the Civil War. Chicago: University of Chicago Press. pp. 173-216.

Martorell, Reynaldo, and Jean Pierre Habicht. 1986. "Growth in Early Childhood in Developing Countries." In Frank Faulkner and J.M. Tanner, eds. Human Growth: A Comprehensive Treatise. Vol. 3. NY: Plenum Press. pp. 241-262.

New York State. Secretary of State. 1867. Census of the State of New York for 1865. Albany, NY: C. Van Benthuysen \& Sons.

New York State. Secretary of State. 1877. Census of the State of New York for 1875. Albany, NY: Weed, Parsons \& Co.

Pessen, Edward. 1971. "The Egalitarian Myth and American Social Reality: Wealth, Mobility, and Equality in the "Era of the Common Man'". American Historical Review. Vol. 76 (October). pp. 1004-1029.

Pope, Clayne L. 1992. "Adult Mortality in America before 1900: A View from Family Histories." In Claudia Goldin and Hugh Rockoff, eds. Strategic Factors in Nineteenth Century American Economic History: A Volume to Honor Robert W. Fogel (Chicago: University of Chicago Press). pp. 267-296. Rosenberg, Charles. 1962. The Cholera Years: The United States in 1832, 1849, and 
1866. Chicago: University of Chicago Press.

Rosenwaike, Ira. 1972. Population History of New York City. Syracuse, NY: Syracuse University Press.

Shannon, Fred. 1928. The Organization and Administration of the Union Army, 2 vols. Gloucester, MA: P. Smith.

Steckel, Richard H. 1992. "Stature and Living Standards in the United States." In Robert E. Gallman and John Joseph Wallis, eds., Economic Growth and Standards of Living before the Civil War. Chicago: University of Chicago Press. pp. 265-308. Steckel, Richard H. 1995. "Stature and the Standard of Living." Journal of Economic Literature. Vol. 33 (December). pp. 1903-1940.

Steckel, Richard H., and Donald R. Haurin. 1990. "Health and Nutrition in the American Midwest: Evidence from the Height of Ohio National Guardsmen, 1850-1910." Ohio State University. Columbus, OH. Manuscript.

Szreter, Simon. 1997. "The Politics of Public Health in Nineteenth-Century Britain." Population and Development Review. Vol. 23, No. 4 (December). pp. 693-728.

Szreter, Simon, and Graham Mooney. 1998. "Urbanization, Mortality, and the Standard of Living Debate: New Estimates of the Expectation of Life at Birth in NineteenthCentury British Cities." Economic History Review. Vol. 51, No. 1 (February). pp. 84112 .

Taylor, George Rogers. 1951. The Transportation Revolution, 1815-1860. Chicago: Holt, Rinehart, and Winston.

U.S. Bureau of the Census. 1864. U.S. Census of Population: 1860. Vol. 1. "Population." Washington, DC: G.P.O.

U.S. Bureau of the Census. 1866. U.S. Census of Population: 1860. "Statistics of the United States, (including Mortality, Property \&C, ) in 1860." Washington, DC: G.P.O.

U.S. Bureau of the Census. 1933. U.S. Census of Population: 1930. "Abstract of the Fifteenth Census of the United States." Washington, DC: G.P.O.

U.S. Bureau of the Census. 1975. Historical Statistics of the United States: Colonial Times to 1970. Washington, DC: G.P.O.

Vinovskis, Maris. 1978. "The Jacobson Life Table of 1850: A Critical Re- examination from a Massachusetts Perspective," Journal of Interdisciplinary History. Vol. 8, No. 4 (Spring). pp. 703-24.

Weiss, Thomas. 1992. "U.S. Labor Force Estimates and Economic Growth, 1800-1860." In Robert E. Gallman and John Joseph Wallis, eds. American Economic growth and Standards of Living Before the Civil War. Chicago: University of Chicago Press. pp. 19-78. Wilentz, Sean. 1984. Chants Democratic: New York City and the Rise of the American 
Working Class, 1788-1850. NY: Oxford University Press. 
Table 1. Selected Economic \& Social Data for the United States. 1800-1860.

(1)

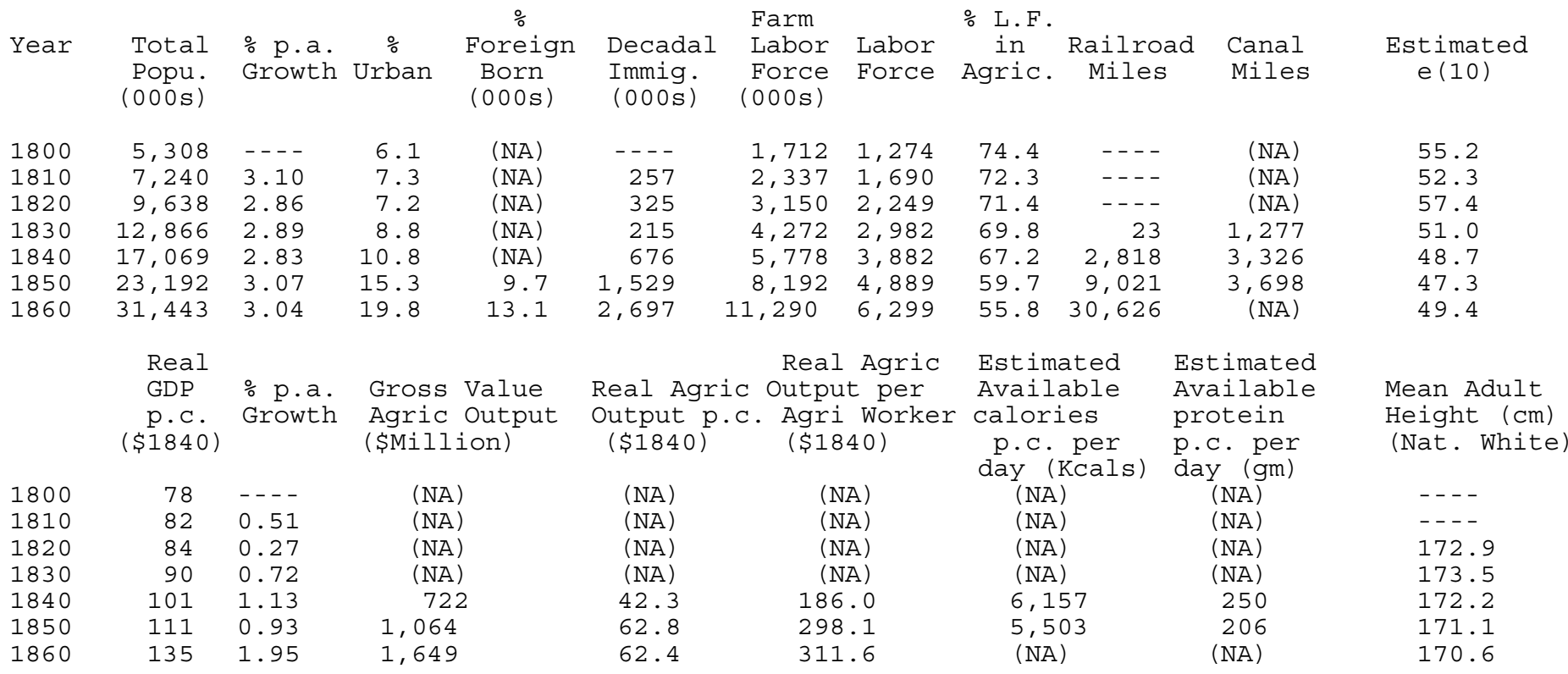

(1) Data for real GDP per capita, value of agricultural production, calories per capita, \& protein per capita apply to the year prior to the census (i.e., 1799, 1809, ...1859). Decadal growth rates and decadal immigration apply to the decade prior to the census date.

Source: (a) Total, urban, and foreign-born population; railroad miles; decadal immigration: U.S. Bureau of the Census [1975], series A-2, A-57, A-105, 112; Q-321; C-89. (b) Labor force, farm labor force, real GDP per capita: Weiss [1992], Tables 1.1, 1.2. (c) Gross value of agricultural output calculated from physical output and value data in the agricultural censuses of 1840, 1850, \& 1860 and prices from Craig [1993], Table A.1 Real agricultural output per capita and per worker is calculated by deflating by the price index in U.S. Bureau of the Census [1975], series E-52. (d) For estimated calories and protein, see text.

(e) Estimated mean adult male height and estimated e(10): Steckel [1992], Table 6.8. Originally based on Fogel [1986] and Steckel and Haurin [1990]. (f) Canal mileage: Taylor [1951], ch. III. 
Table 2. Variable Names, Definitions, and Descriptive Statistics of County-Level Variables

\begin{tabular}{|c|c|c|c|}
\hline Variable & Definition & & ion \\
\hline CDR & $\begin{array}{l}\text { Crude death rate in the county } \\
\text { (per } 1,000 \text { population) }\end{array}$ & 18.04 & 8.784 \\
\hline PROTEIN & $\begin{array}{l}\text { Surplus protein production } \\
\text { (100s of grams per adult equivalent per }\end{array}$ & $\begin{array}{l}2.144 \\
\text { day) }\end{array}$ & 1.594 \\
\hline CALORIES & $\begin{array}{l}\text { Surplus calorie production } \\
\text { (Kcals per adult equivalent per day) }\end{array}$ & 3.017 & 3.780 \\
\hline $\mathrm{HP}$ & $\begin{array}{l}\text { Herfindahl Index for protein } \\
\text { production }\end{array}$ & 0.4577 & 0.0888 \\
\hline $\mathrm{HC}$ & $\begin{array}{l}\text { Herfindahl Index for calorie } \\
\text { production }\end{array}$ & 0.5199 & 0.1142 \\
\hline WEALTH Value & $\begin{array}{l}\text { of agricultural land, live- } \\
\text { stock, and implements and } \\
\text { manufacturing capital (\$ per capita) }\end{array}$ & 148.7 & 86.80 \\
\hline TRANSPORT & $\begin{array}{l}1 \text { if the county was on a } \\
\text { waterway, } 0 \text { otherwise }\end{array}$ & 0.4905 & 0.5001 \\
\hline URBAN & $\begin{array}{l}\text { Proportion of a county's } \\
\text { population residing in an urban area }\end{array}$ & 0.0250 & 0.1069 \\
\hline
\end{tabular}


Table 3. Mean Crude Death Rate by County

\begin{tabular}{|c|c|c|c|}
\hline $\begin{array}{c}\text { Number of } \\
\text { Observations }\end{array}$ & Mean & $\begin{array}{l}\text { Standard } \\
\text { Deviation }\end{array}$ & t-stat \\
\hline \multicolumn{4}{|l|}{ County with a nutritional: } \\
\hline Surplus $\quad 1196$ & 17.774 & 8.516 & \\
\hline Deficit & 21.839 & 11.507 & $3.104 * * *$ \\
\hline \multicolumn{4}{|l|}{ County with Herfindahl Index: } \\
\hline Less than $0.50 \quad 946$ & 18.039 & 9.088 & \\
\hline From 0.50 to 0.75 & 17.768 & 7.875 & 0.505 \\
\hline Greater than 0.75 & 21.567 & 6.803 & $2.396 * *$ \\
\hline \multicolumn{4}{|c|}{ County with per capita wealth: } \\
\hline Less than $\$ 100 \quad 419$ & 15.863 & 7.827 & \\
\hline From $\$ 100$ to $\$ 250$ & 18.704 & 8.708 & $5.640 * * *$ \\
\hline Greater than $\$ 250$ & 20.877 & 10.258 & $2.423 * *$ \\
\hline \multicolumn{4}{|l|}{ County with: } \\
\hline TRANSPORT $=0$ & 15.606 & 6.774 & \\
\hline TRANSPORT $=1$ & 20.544 & 9.864 & $10.384 * * *$ \\
\hline \multicolumn{4}{|l|}{ County with URBAN share: } \\
\hline Less then 1\% 1177 & 17.660 & 8.596 & \\
\hline From $1 \%$ to $25 \%$ & 19.226 & 5.256 & $1.960 * *$ \\
\hline Greater then $25 \%$ & 25.393 & 11.981 & $3.349 * * *$ \\
\hline \multicolumn{4}{|c|}{$\begin{array}{l}\text { Notes: The t-statistic was calculated to test the hypothesis that the mean CDR of the } \\
\text { counties in that group differed from that of the counties in the group immediately above } \\
\text { it. Nutritional surplus or deficit and the Herfindahl index was measured using protein } \\
\text { availability. N=1276. } \\
\text { **The probability of obtaining a t-statistic this large when the null hypothesis that } m_{i} \\
\text { not equal to m is true is less than 0.05. } \\
\text { ** The probability of obtaining a t-statistic this large when the null hypothesis that } \mathrm{m}_{i} \\
\text { not equal to } \mathrm{m}_{\mathrm{j}} \text { is true is less than } 0.01 \text {. }\end{array}$} \\
\hline
\end{tabular}


Table 4. Regression Results for County-Level Crude Death Rates

\begin{tabular}{|c|c|c|c|c|}
\hline Variable & (1) & (2) & (3) & $(4)$ \\
\hline INTERCEPT & $\begin{array}{l}13.2420 * * * \\
(0.6014)\end{array}$ & $\begin{array}{l}9.8201 * * * \\
(1.3830)\end{array}$ & $\begin{array}{l}13.6550 * * * \\
(0.4906)\end{array}$ & $\begin{array}{l}9.4004 \text { * } \\
(1.2684)\end{array}$ \\
\hline PROTEIN & $\begin{array}{c}0.2170 \\
(0.1531)\end{array}$ & $\begin{array}{c}0.2008 \\
(0.1645)\end{array}$ & - & - \\
\hline CALORIES & - & - & $\begin{array}{c}.0607 \\
(0.0650)\end{array}$ & $\begin{array}{l}-0.0235 \\
(0.0742)\end{array}$ \\
\hline $\mathrm{HP}$ & - & $\begin{array}{l}6.9840 * * \\
(2.8192)\end{array}$ & - & - \\
\hline $\mathrm{HC}$ & - & - & - & $\begin{array}{c}8.2000 * \\
(2.3331)\end{array}$ \\
\hline WEALTH & $\begin{array}{l}0.0137 * * * \\
(0.0027)\end{array}$ & $\begin{array}{l}0.0147 * * * \\
(0.0028)\end{array}$ & $\begin{array}{l}0.0132 * * * \\
(0.0029)\end{array}$ & $\begin{array}{c}0.0137 * \\
(0.0029)\end{array}$ \\
\hline TRANSPORT & $\begin{array}{l}3.9475 * * * \\
(0.4927)\end{array}$ & $\begin{array}{l}3.9758 * * * \\
(0.4943)\end{array}$ & $\begin{array}{l}3.8808 * * * \\
(0.4889)\end{array}$ & $\begin{array}{c}4.0525 * \\
(0.4918)\end{array}$ \\
\hline URBAN & $\begin{array}{l}13.4107 * * * \\
(2.2653)\end{array}$ & $\begin{array}{l}14.6486 * * * \\
(2.2826)\end{array}$ & $\begin{array}{l}12.9932 * * * \\
(2.2326)\end{array}$ & $\begin{array}{l}13.7994 * \\
(2.2294)\end{array}$ \\
\hline $\begin{array}{l}\mathrm{R}^{2}(\operatorname{adj}) \\
\mathrm{F} \\
\mathrm{N}\end{array}$ & $\begin{array}{l}43.49 * * * \\
1274\end{array}$ & $\begin{array}{l}0.117 \\
36.46 * * * \\
1260\end{array}$ & $\begin{array}{c}0.126 \\
43.17 * \star * \\
1274\end{array}$ & $\begin{array}{l}37.39 * * * \\
1260\end{array}$ \\
\hline \multicolumn{5}{|c|}{$\begin{array}{l}\text { Notes: Standard errors are in parentheses. } \\
\quad * \text { The probability of obtaining a coefficient this large when the null hypothesis that } \\
\beta_{i}=0 \text { is true is less than } 0.10 \text {. } \\
* * \text { The probability of obtaining a coefficient this large when the null hypothesis that } \\
\beta_{i}=0 \text { is true is less than } 0.05 \text {. } \\
* * * \text { The probability of obtaining a coefficient this large when the null hypothesis that } \\
\beta_{i}=0 \text { is true is less than } 0.01 .\end{array}$} \\
\hline
\end{tabular}


Table 5. Variable Names, Definitions, and Descriptive Statistics of Variables for Individual Recruits

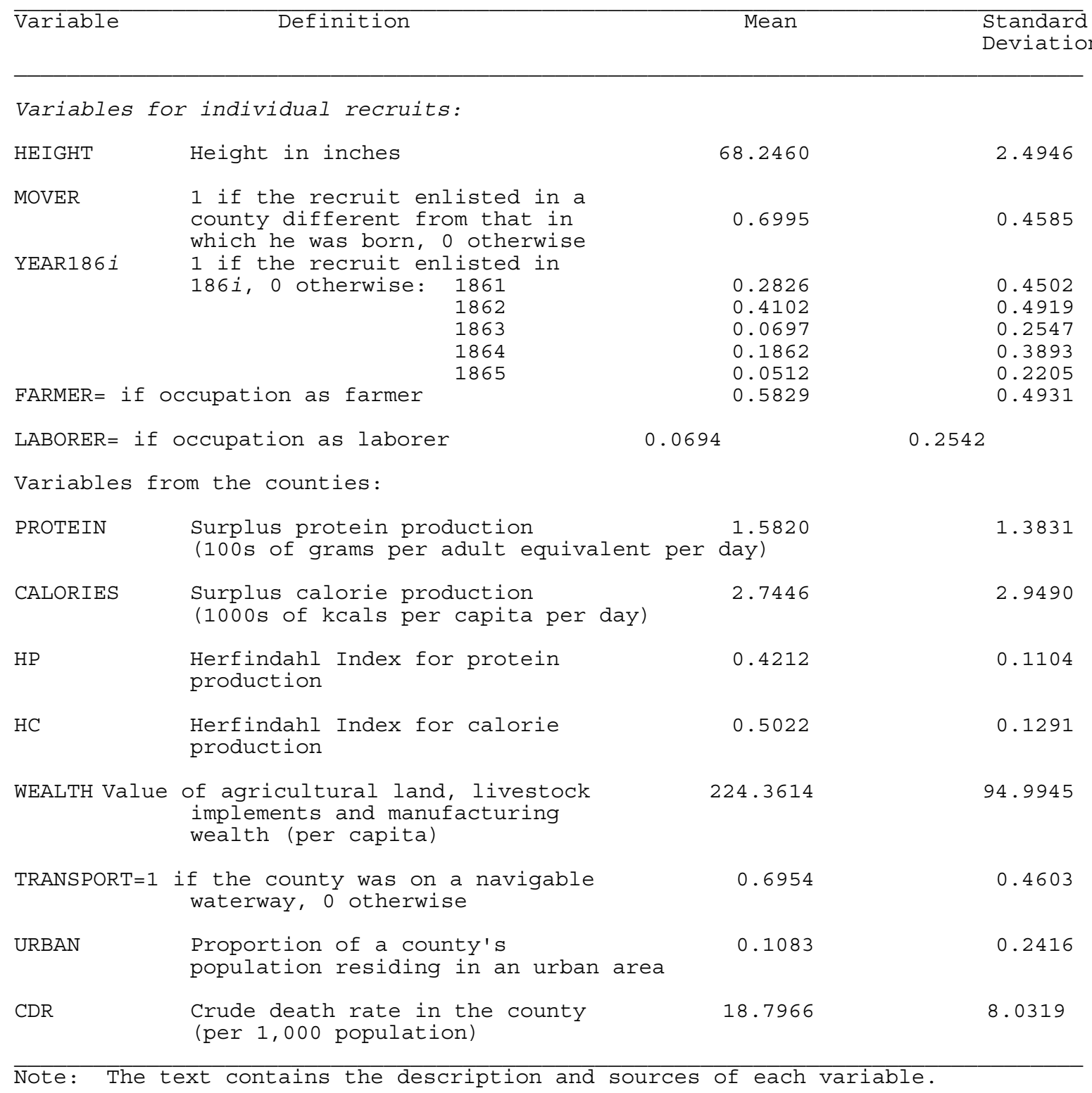


Table 6. Mean Heights of Various Groups

\begin{tabular}{|c|c|c|c|c|}
\hline \multirow{2}{*}{ Variable } & \multirow{2}{*}{$\begin{array}{l}\text { Number of } \\
\text { Observations }\end{array}$} & \multicolumn{3}{|c|}{ Standard } \\
\hline & & Mean & Deviation & t-stat \\
\hline "MOVER" & 4559 & 68.2973 & 2.4294 & \\
\hline "STAYER" & 1963 & 68.1269 & 2.6368 & $2.4502 * \star$ \\
\hline \multicolumn{5}{|l|}{ Enlistment Year: } \\
\hline 1861 & 1837 & 68.2903 & 2.5618 & \\
\hline 1862 & 2678 & 68.3188 & 2.4865 & 0.3721 \\
\hline 1863 & 456 & 68.0866 & 2.4891 & $1.8418 *$ \\
\hline 1864 & 1217 & 68.2061 & 2.3925 & 0.8834 \\
\hline 1865 & 334 & 67.7807 & 2.5096 & $2.7716 * \star \star$ \\
\hline \multicolumn{5}{|l|}{ Occupation: } \\
\hline FARMER & 3803 & 68.5410 & 2.5036 & \\
\hline Not a FARMER & 2719 & 67.8334 & 2.4231 & $11.4675 * * *$ \\
\hline LABORER & 453 & 68.0081 & 2.3154 & \\
\hline Not a LABORER & 6069 & 68.2637 & 2.5068 & $2.2538 * *$ \\
\hline \multicolumn{5}{|c|}{ County with a Nutritional: } \\
\hline Surplus & 5972 & 68.3462 & 2.4846 & \\
\hline Deficit & 550 & 67.1577 & 2.3412 & $11.3324 * * *$ \\
\hline \multicolumn{5}{|c|}{ County with Herfindahl Index: } \\
\hline Less than 0.50 & 4839 & 68.1699 & 2.5141 & \\
\hline From 0.50 to 0.75 & 1681 & 68.4665 & 2.4260 & $4.2787 * * *$ \\
\hline \multicolumn{5}{|c|}{ County with per capita wealth: } \\
\hline Less than $\$ 100$ & 496 & 67.9277 & 2.5038 & \\
\hline From $\$ 100$ to $\$ 250$ & 3508 & 68.3930 & 2.5475 & $3.8652 * \star \star$ \\
\hline Greater than $\$ 250$ & 2511 & 68.1089 & 2.4031 & $4.4096 * * *$ \\
\hline \multicolumn{5}{|l|}{ County with: } \\
\hline TRANSPORT=1 & 4539 & 68.0652 & 2.5107 & \\
\hline TRANSPORT $=0$ & 1983 & 68.6597 & 2.4076 & $9.0529 * \star *$ \\
\hline \multicolumn{5}{|c|}{ County with URBAN share: } \\
\hline Less then $1 \%$ & 4720 & 68.4627 & 2.4957 & \\
\hline From 1\% to $25 \%$ & 888 & 68.0214 & 2.4204 & $4.9594 * \star \star$ \\
\hline Greater than 25\% & 914 & 67.3451 & 2.3366 & $6.0321 * * *$ \\
\hline \multicolumn{5}{|l|}{ County with CDR: } \\
\hline Less then 10 & 228 & 68.6400 & 2.6139 & \\
\hline From 10 to 25 & 5304 & 68.3071 & 2.4764 & $1.8867 \star$ \\
\hline Greater than 25 & 990 & 67.8277 & 2.5204 & $5.5092 * * *$ \\
\hline
\end{tabular}

Notes: The t-statistic was calculated to test the hypothesis that the mean height of the individuals in that group differed from that of the group immediately above it.

***The probability of obtaining a t-statistic this large when the null hypothesis that $m_{i}$ not equal to $\mathrm{m}_{j}$ is true is less than 0.01 . Nutritional surplus or deficit and the Herfindahl index are for protein availability. 
Table 7. Regression Results for Heights of Union Army Recruits

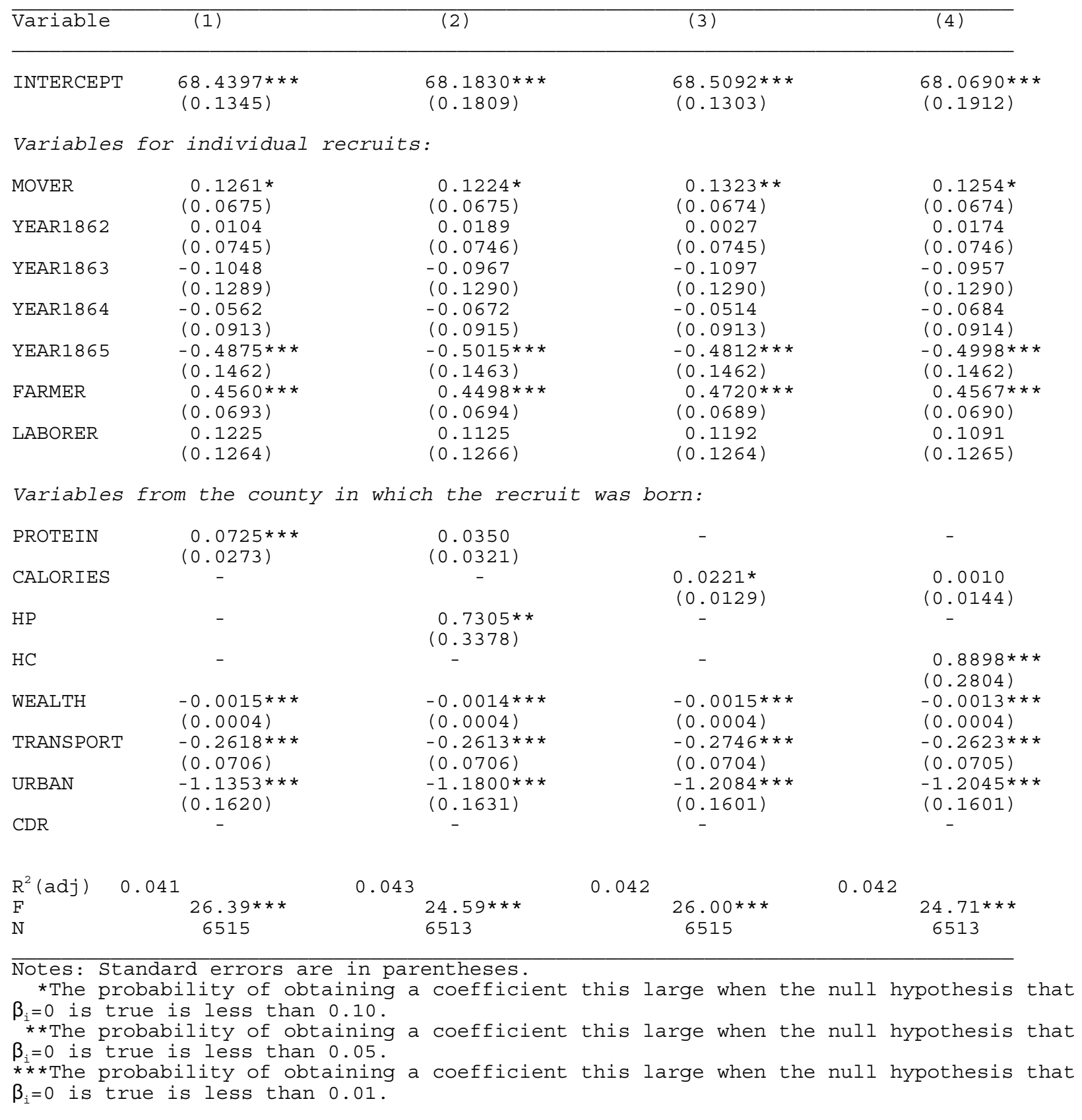


Table 7. Regression Results for Heights of Union Army Recruits (Cont.)

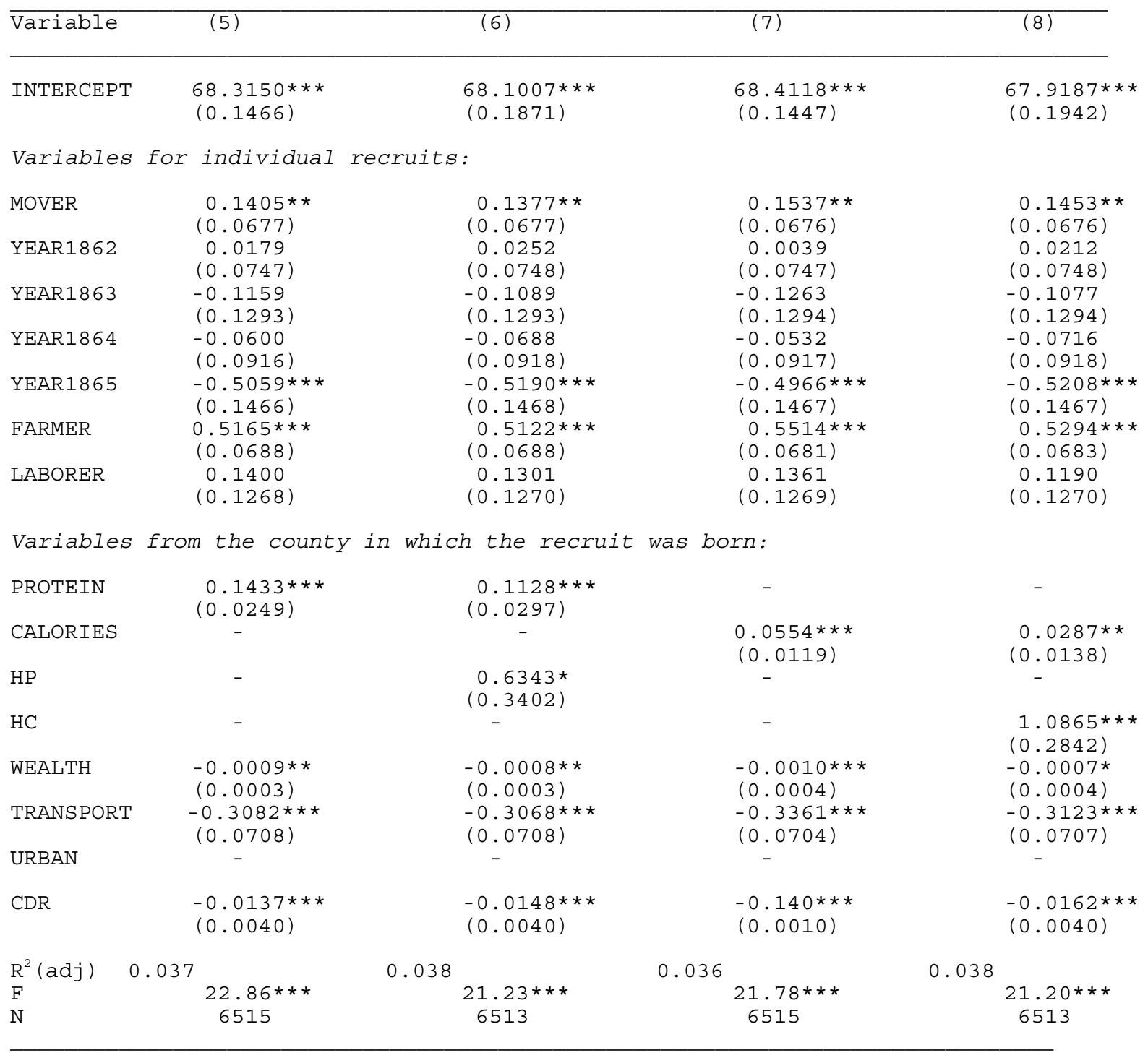


FIGURE 1

Fig. 6.2from Steckel

[1990].

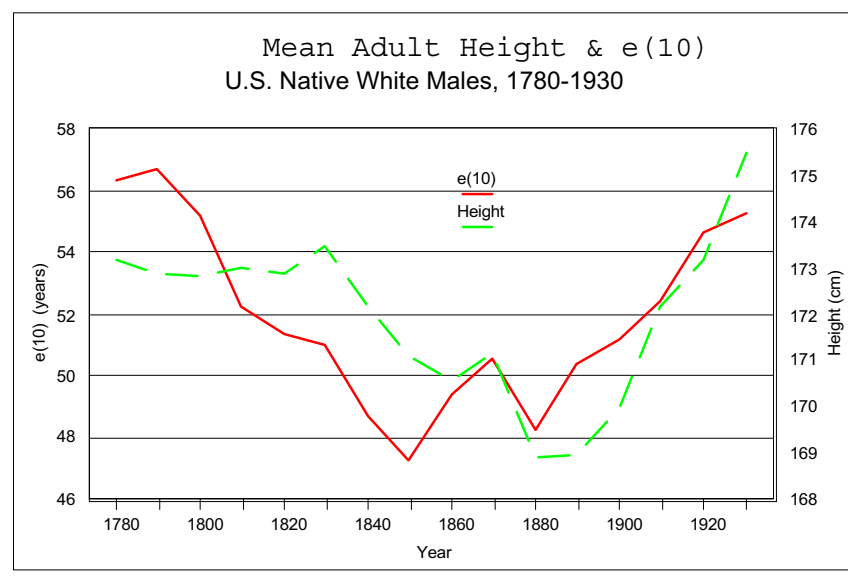

Source: Steckel [1992]

Fogel [1986] and

and Haurin 


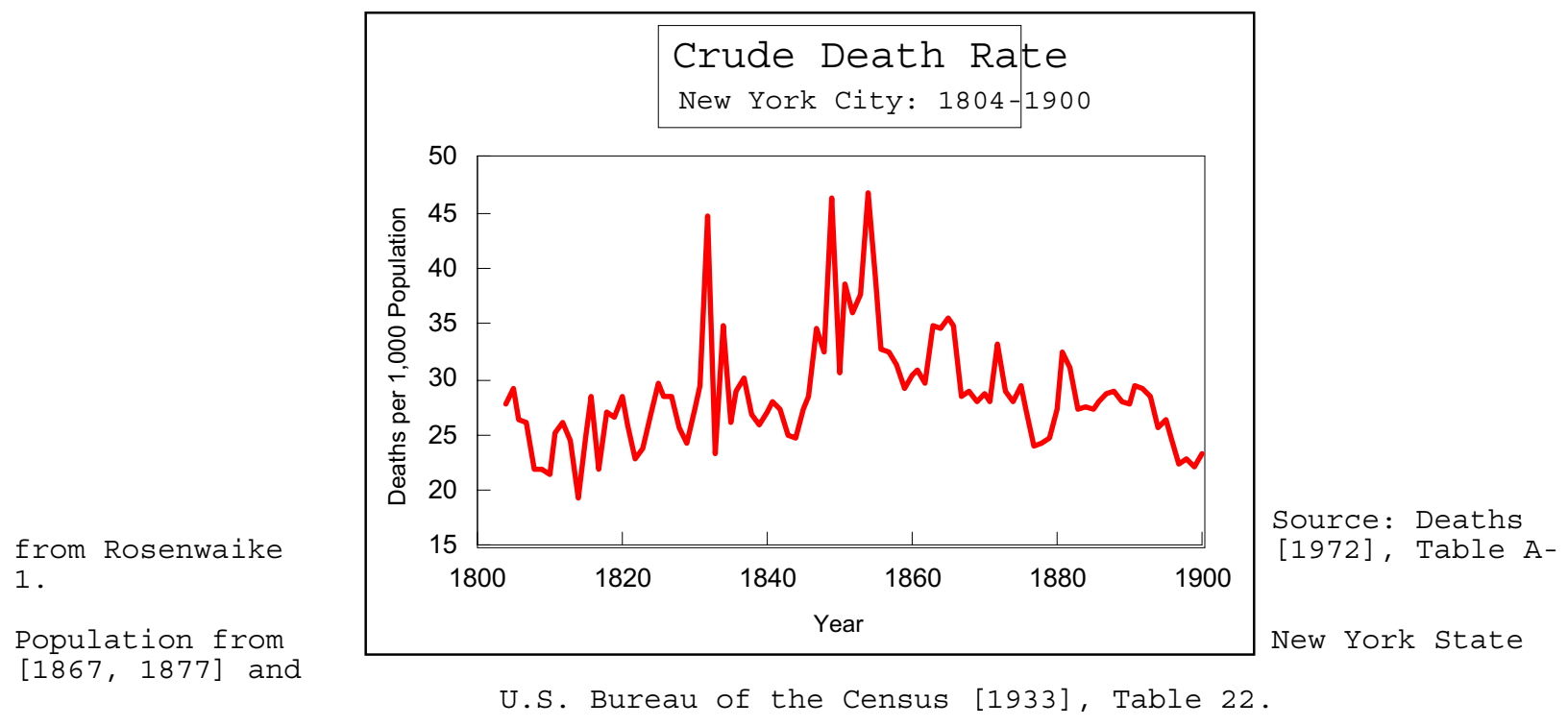


1. Gallman's figures for the eighteenth century, which are summarized in Atack and Passell [1994, p. 4], show growth of 0.48 percent per year between 1710 and 1775. Mancall and Weiss [1997] conjecture that growth was even slower.

2. This estimate is calculated from figures reported in Margo [1992, p. 187]. Margo reports a number of real wage indices, with the slowest growing index showing a rate of increase of $0.72 \%$ per annum over the same period.

3. Gallman [1995, 1996] challenges the underlying assumptions and figures that support both of these assertions.

4. The Death Registration Area was formed in 1900 from ten states (Maine, New Hampshire, Vermont, Massachusetts, Rhode Island, Connecticut, New York, New Jersey, Indiana, and Michigan) and the District of Columbia. These areas were deemed to have acceptable levels of death registration. The Death Registration Area was then expanded until it included the entire United States (by 1933).

5. There are no mortality data available for the 1840 census. The assumption here is that there was substantial correlation over time in death rates, so that the 1850 rates will capture relative differences in 1840. The same argument is made for the WEALTH variable. Manufacturing wealth is available from the 1840 census, but not agricultural wealth. The census crude death rate for 1850 for states was correlated .63 with that for 1860. The correlation for 1860 and 1870 was .62.

6. The Herfindahl index is the sum of the squares of the shares of the sources of nutrition; thus if all of the nutrients came from one source, then HINDEX would equal 1. Conversely, the smaller the shares, the less the concentration, and HINDEX approaches zero.

7. Urban population by county was reconstructed from the original worksheets of the Census Bureau, work done for the 1930 census. Urban population is defined as population in incorporated areas of 2,500 persons and over.

8. The calculation of these variables is discussed in detail in Craig and Weiss [1997].

9. These conversions followed a two-step processes. First, we converted the physical quantities to weight using the information provided by Lipton [1995, Appendix 7]. Second, we converted weight into kilograms of protein and energy (kcals) using the conversion rates in Ensminger et al. [1994, Table P-37].

10. The results reported below are from a "moderate" set of estimates which lie between upper and lower bounds derived from figures supplied by Gallman [1996] and Komlos [1996]. Our "moderate" consumption estimates are as follows: adult males=3,300 calories, adult females and teenagers=2,700, and children=1000. The estimates of consumption by livestock come from Craig [1993, Appendix A]. Although there is considerable debate about the accuracy of such consumption estimates for the 19 th century United States, particularly regarding consumption by humans, the empirical effects of nutrition on other variables affecting height varied little with respect to variation in the consumption requirements. See Craig and Weiss [1997].

11. For 1508 counties matched between 1850 and 1860 by Craig et al. [1998] the correlation coefficient for wealth was 0.96 .

12. This variable was first constructed and employed by Craig et al. [1998] to capture the effects of transportation improvements on land values.

13. Transportation access and urbanization are both correlated with immigration; furthermore, to the extent that the economic infrastructure was stretched by immigration, and to the extent that immigrants achieved lower living standards, at least by biological measures, immigration probably played an important role in any Malthusian squeeze.

14. Much of the material in this section, particularly as it relates to the theoretical arguments and discussion of the data, is taken from Craig and Weiss [1998], and a more complete treatment can be found there. 
15. Of course, agricultural production varied from year to year, but for those born before 1840, local deviations from long-run means would have been random and by increasing the standard errors of the resulting estimates would tend to bias against falsely rejecting the null hypothesis that net nutrition did not affect stature. With respect to recruits born after 1840, if 1840 were an unusually productive year locally, then as both Gallman [1996] and Komlos [1996] note, storage, although not well recorded, would have tended to convey surpluses into the next season or two, thus still affecting infants born after the 1840 crop year. If 1840 were an unusually bad year, then at the margin some families would have faced an increase in the relative price of nutrients and either depleted their wealth or altered consumption bundles accordingly, thus affecting the nutrition of infants born in the following year.

16. Galenson and Pope found that the mean wealth for "persisters" was greater than "nonpersisters" in every age category [Galenson and Pope, 1989, p. 644]; however, they also conclude that "Very high levels of economic opportunity may have been a characteristic of the farming frontier (p. 635);" and therefore we would expect movers to be those most likely to seek and take advantage of those opportunities.

17. These two variables were collinear and each interfered with the stable estimation of the effect of the other. The zero-order correlation of the two variables in the restricted sample was 0.533 .

18. A protein surplus of one standard deviation above the mean would have been the same as roughly 168 grams of additional protein per adult equivalent - 24 ounces of pork or 3.5 pounds of whole wheat bread [Ensminger et al., 1994, table P-37]. By any measure, these would be substantial additions to the average antebellum diet. Although we do not know how much any individual was able to augment his diet, these county-level figures suggest that the nutrition available to recruits in surplusproducing counties was abundant.

19. The standard deviations in the current study are shown in Table 5. The comparable figures from the previous study are: for proteins a mean of 91 grams and standard deviation of 71 grams, and for calories a mean of 6,710 calories with a standard deviation of 4,330 calories. 